\title{
Solubility of $\mathrm{TiO}_{2}$ in garnet and orthopyroxene: Ti thermometer for ultrahigh-temperature granulites
}

\author{
Toshisuke Kawasaki, ${ }^{1}$ and Yoichi Motoyoshi ${ }^{2}$ \\ ${ }^{1}$ Department of Earth Sciences, Graduate School of Science and Engineering, Ehime University, Bunkyo-cho 2-5, Matsuyama 790-8577, \\ Japan (toshkawa@sci.ehime-u.ac.jp) \\ ${ }^{2}$ National Institute of Polar Research, Kaga 1-chome, Itabashi-ku, Tokyo 173-8515, Japan (motoyosi@nipr.ac.jp)
}

\begin{abstract}
We report the $\mathrm{TiO}_{2}$ solubility in garnet and orthopyroxene coexisting with rutile calibrated from experimental data at pressures $7-20 \mathrm{kbar}$ and temperatures $850-1300^{\circ} \mathrm{C}$ in two Antarctic granulite systems. The Ti would substitute for the tetrahedral $\mathrm{Si}$, whereas we could not find positive evidence of the coupled substitution of $M-\mathrm{Ti}(M$ is $\mathrm{Mg}$ or Fe) for Al-Al in octahedral sites as well as the interstitial substitution of $\square-\mathrm{Ti}$ ( $\square$ is a vacancy) for $M-M$ in triangular-dodecahedral sites of garnet at ultrahigh-temperature (UHT) metamorphic conditions. The $\mathrm{TiO}_{2}$ content of garnet increases with temperature and decreases with pressure. In orthopyroxene Ti substitutes for atoms in the tetrahedral and octahedral sites. The Ti content of orthopyroxene increases with temperature and increases with pressure. Titanium solubility in garnet and orthopyroxene is not so sensitive to pressure change as compared with temperature dependence given by following empirical equations:
\end{abstract}

$$
\ln \left(X_{\mathrm{Ti}}^{\mathrm{Grt}, \mathrm{IV}} / X_{\mathrm{Si}}^{\mathrm{Grt}, \mathrm{IV}}\right)=-15366 / T+5.962 \text { and } \ln \left(X_{\mathrm{Ti}}^{\mathrm{Opx}, \mathrm{IV}} / X_{\mathrm{Si}}^{\mathrm{Opx}, \mathrm{IV}}\right)=-11367 / T+3.107
$$

where $X$ is the mole fraction of Ti or Si on the tetrahedral sites and temperature is given in Kelvin.

Citation: Kawasaki, T. and Y. Motoyoshi (2007), Solubility of $\mathrm{TiO}_{2}$ in garnet and orthopyroxene: Ti thermometer for ultrahigh-temperature granulites, in Antarctica: A Keystone in a Changing World - Online Proceedings of 10th ISAES, edited by A. K. Cooper and C. R. Raymond et al., USGS Open-File Report 2007-1047, Short Research Paper 038, 4 p.; doi 10.3133/of2007-1047.srp038

\section{Introduction}

Exsolution lamellae of rutile are often observed in the porphyroblastic garnet, orthopyroxene, sapphirine, osumilite, K-feldspar (mesoperthite) and quartz of the UHT granulites from Napier complex, East Antarctica (Kawasaki and Motoyoshi, 2000; Osanai et al., 2001; Osanai and Yoshimura, 2002) and also found in garnet and clinopyroxene of the ultrahigh-pressure (UHP) eclogites and peridotites as well as ilmenite rods in olivine (Dobrzhinetskaya et al., 1996; Song et al., 2004). Some authors have proposed the hypothesis that $\mathrm{TiO}_{2}$ dissolves into silicates at peak metamorphism and then rutile precipitates from the $\mathrm{TiO}_{2}-$ saturated hosts during the subsequent retrograde decompression metamorphism (Dobrzhinetskaya et al., 1996; Green et al., 1997; Song et al., 2004) or cooling metamorphism (Wark and Watson, 2006; Kawasaki and Osanai, 2007).

In this paper we present the new experimental data at $15-20 \mathrm{kbar}$ and $1200-1300^{\circ} \mathrm{C}$ in the $\mathrm{SiO}_{2}-$ $\mathrm{TiO}_{2}-\mathrm{Al}_{2} \mathrm{O}_{3}$ doped McIntyre granulite (Kawasaki and Motoyoshi, 2000) system, and compile the previously published data on the high-pressure and hightemperature phase relations of the Runvågshetta granulite (Kawasaki and Motoyoshi, 2005) at pressures 7$15 \mathrm{kbar}$ and temperatures $850-1150^{\circ} \mathrm{C}$ to determine the pressure-temperature dependence of the $\mathrm{TiO}_{2}$ solubility and to develop a Ti-geothermobarometer.

\section{Experimental procedures Starting materials}

The starting material, which is highly saturated in $\mathrm{TiO}_{2}$ (MCTQ), was prepared by adding $8 \mathrm{wt} \% \mathrm{Al}_{2} \mathrm{O}_{3}$
+16 wt $\% \mathrm{TiO}_{2}+8$ wt $\% \mathrm{SiO}_{2}$ to McIntyre granulite (Kawasaki and Motoyoshi, 2000; Kawasaki et al., 2002). The mixture was fused at $10.5 \mathrm{kbar}$ and $1700^{\circ} \mathrm{C}$ for 2 minutes in a graphite capsule using the piston-cylinder apparatus. Chemical compositions of $\mathrm{SiO}_{2}-\mathrm{TiO}_{2}-\mathrm{Al}_{2} \mathrm{O}_{3}$ doped McIntyre granulite (MCTQ) and the Runvågshetta granulite $(\mathrm{RVH})$ are given in Table 1 .

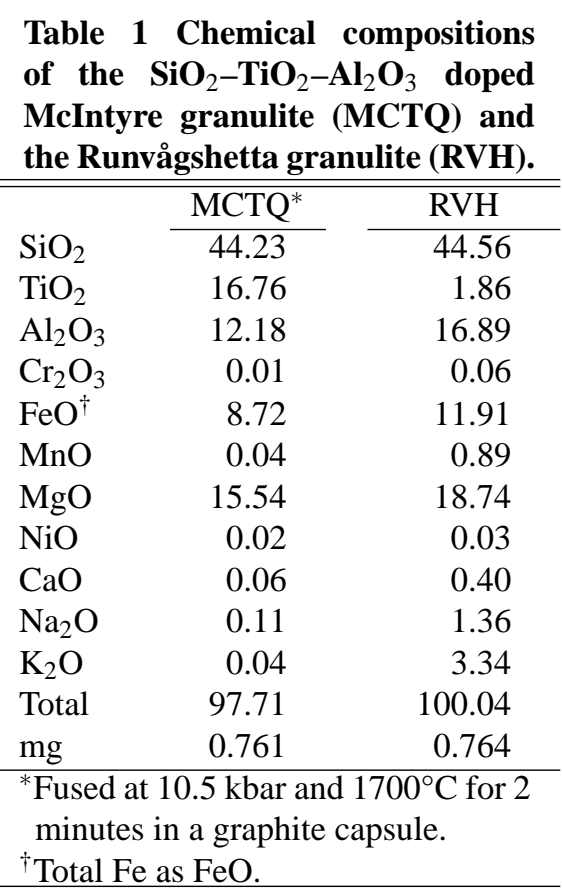

\section{Experimental techniques}

High-pressure experiments were carried out using a $16.0 \mathrm{~mm}$ piston-cylinder apparatus at Ehime Univer- 
Table 2. Representative electron microanalyses of run products.

\begin{tabular}{|c|c|c|c|c|c|c|}
\hline \\
\hline Run No. & \multicolumn{2}{|c|}{ 050607D } & \multicolumn{2}{|c|}{$050726 \mathrm{C}$} & \multicolumn{2}{|c|}{ 051205B } \\
\hline$P$, kbar & \multicolumn{2}{|c|}{15} & \multicolumn{2}{|c|}{20} & \multicolumn{2}{|c|}{17.5} \\
\hline$T,{ }^{\circ} \mathrm{C}$ & \multicolumn{2}{|c|}{1200} & \multicolumn{2}{|c|}{1300} & \multicolumn{2}{|c|}{1200} \\
\hline Duration, hrs & \multicolumn{2}{|c|}{266} & \multicolumn{2}{|c|}{238} & \multicolumn{2}{|c|}{106} \\
\hline Phase & Opx & Grt & Opx & Grt & Opx & Grt \\
\hline $\mathrm{SiO}_{2}$ & $\frac{1}{48.001}$ & 40.322 & 50.624 & 43.019 & 49.282 & 41.738 \\
\hline $\mathrm{TiO}_{2}$ & 1.587 & 1.342 & 1.539 & 1.253 & 1.289 & 1.603 \\
\hline $\mathrm{Al}_{2} \mathrm{O}_{3}$ & 12.643 & 23.504 & 10.485 & 25.027 & 12.118 & 23.949 \\
\hline $\mathrm{Cr}_{2} \mathrm{O}_{3}$ & 0.030 & 0.010 & n.d. & n.d. & 0.026 & n.d. \\
\hline $\mathrm{FeO}$ & 11.502 & 12.828 & 7.384 & 5.401 & 8.026 & 9.837 \\
\hline $\mathrm{MnO}$ & 0.041 & 0.073 & 0.035 & 0.085 & 0.065 & 0.088 \\
\hline $\mathrm{MgO}$ & 25.975 & 20.309 & 29.612 & 26.318 & 28.450 & 22.807 \\
\hline $\mathrm{NiO}$ & 0.023 & 0.024 & n.d. & 0.012 & n.d. & 0.006 \\
\hline $\mathrm{CaO}$ & 0.031 & 0.174 & 0.048 & 0.147 & 0.056 & 0.214 \\
\hline $\mathrm{Na}_{2} \mathrm{O}$ & 0.101 & 0.024 & 0.185 & 0.043 & 0.112 & 0.013 \\
\hline $\mathrm{K}_{2} \mathrm{O}$ & 0.016 & 0.006 & 0.011 & 0.008 & 0.019 & 0.004 \\
\hline Total & 99.951 & 98.616 & 99.921 & 101.31 & 99.443 & 100.259 \\
\hline \multicolumn{7}{|c|}{ Number of cations for $N$ oxygens } \\
\hline$N$ & 6 & 12 & 6 & 12 & 6 & 12 \\
\hline $\mathrm{Si}$ & 1.7010 & 2.9232 & 1.7589 & 2.9297 & 1.7260 & 2.9328 \\
\hline $\mathrm{Ti}$ & 0.0423 & 0.0732 & 0.0402 & 0.0642 & 0.0339 & 0.0847 \\
\hline $\mathrm{Al}$ & 0.5280 & 2.0083 & 0.4294 & 2.0088 & 0.5002 & 1.9834 \\
\hline $\mathrm{Cr}$ & 0.0008 & 0.0006 & - & - & 0.0007 & - \\
\hline $\mathrm{Fe}$ & 0.3409 & 0.7777 & 0.2146 & 0.3076 & 0.2351 & 0.5781 \\
\hline $\mathrm{Mn}$ & 0.0012 & 0.0045 & 0.001 & 0.0049 & 0.0019 & 0.0052 \\
\hline $\mathrm{Mg}$ & 1.3722 & 2.1949 & 1.5338 & 2.672 & 1.4854 & 2.3891 \\
\hline $\mathrm{Ni}$ & 0.0007 & 0.0014 & - & 0.0007 & - & 0.0003 \\
\hline $\mathrm{Ca}$ & 0.0012 & 0.0135 & 0.0018 & 0.0107 & 0.0021 & 0.0161 \\
\hline $\mathrm{Na}$ & 0.0069 & 0.0034 & 0.0125 & 0.0057 & 0.0076 & 0.0018 \\
\hline $\mathrm{K}$ & 0.0007 & 0.0006 & 0.0005 & 0.0007 & 0.0008 & 0.0004 \\
\hline Total & 3.9961 & 8.0012 & 3.9926 & 8.0049 & 3.9938 & 7.9919 \\
\hline
\end{tabular}

pyroxene. Garnet always contains fine crystals of quartz and rare rutile. Orthopyroxene has no inclusions.

\section{Chemical analyses}

Chemical analyses of run products were made using an electron microprobe analyser JEOL JXA-8800 Superprobe at Ehime University. Standards of known composition included synthetic quartz for $\mathrm{Si}$, rutile for $\mathrm{Ti}$, corundum for Al, eskolaite for $\mathrm{Cr}$, hematite for $\mathrm{Fe}$, manganese oxide for Mn, nickel oxide for $\mathrm{Ni}$, periclase for $\mathrm{Mg}$, wollastonite for $\mathrm{Ca}$, natural albite for $\mathrm{Na}$ and natural orthoclase for $\mathrm{K}$. The instrumental conditions were: the accelerating voltage, $15 \mathrm{KV}$; electron beam current, $0.01 \mu \mathrm{A}$; beam diameter, 1-2 $\mu \mathrm{m}$ estimated from the size of contamination spots by excitation during analysis. First-order $K_{\alpha}$ wavelengths were used for all oxides and data reduction used the ZAF correction procedure. Analysis of $\mathrm{Ti}$ was made by 30 -sec measure-

sity. Run conditions were pressures $15,17.5$ and 20 kbar and temperatures 1200 and $1300^{\circ} \mathrm{C}$. Run durations were 106-266 hours. We used the $\mathrm{Ag}_{70} \mathrm{Pd}_{30}$ capsule and $\mathrm{Mo} / \mathrm{Pt}$ double capsule for the sample container, two edges of which were sealed by welding. The sample container was put into a boron nitride rod, which was placed between two $\mathrm{MgO}$ rods in a graphite heater within a talc + Pyrex glass assembly. The hot piston-in technique was applied for all runs.

Temperatures were monitored with $\mathrm{Pt} / \mathrm{Pt}_{87} \mathrm{Rh}_{13}$ thermocouple without any correction for the pressure effect on emf. During each experiment the temperature and pressure were kept constant within $\pm 5^{\circ} \mathrm{C}$ and \pm 0.1 kbar of the nominal values. At the end of the run the sample was quenched by cutting off the electric power. The thermocouple reading dropped below $50^{\circ} \mathrm{C}$ in a few seconds and to the ambient temperature in several tens of seconds. The pressure was then released to an atmospheric pressure and the run product was recovered.

\section{Run products}

All run products were mounted in epoxy resin and polished for examination by microprobe analysis. An example of run products is shown in Figure 1. Quartz and rutile are several $\mu \mathrm{ms}$ in grain size and found between grains of euhedral garnet and subhedral ortho-

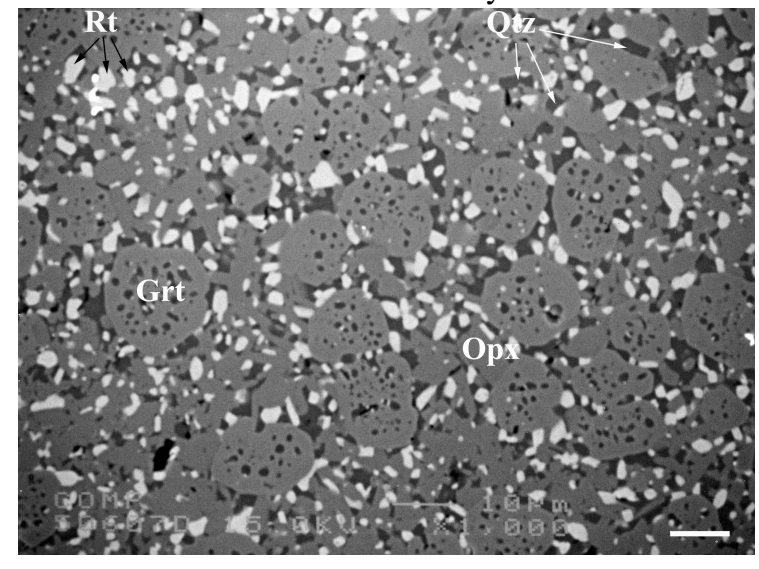

Figure 1. Back scattered electron image (BSEI) of a run product (no. 050607D) synthesized at $15 \mathrm{kbar}$ and $1200^{\circ} \mathrm{C}$ for 266 hours in the $\mathrm{Mo} / \mathrm{Pt}$ double capsule. Garnet (Grt) includes quartz (Qtz) and rutile (Rt). Orthopyroxene (Opx) is found as subhedral crystal without inclusions. White bar indicates $10 \mu \mathrm{m}$.

ments and the others were made by 10 -sec measurements. The background correction was employed for each spot. Detection limit of Ti was about 200 ppm.

\section{Experimental results}

\section{Stoichiometric constraints}

It is clear that $\mathrm{Ti}$ is soluble in garnet and or- 
thopyroxene. The Ti-bearing components are given by the following chemical formulae: $M_{3}^{\mathrm{VIII}} \mathrm{Al}_{2}^{\mathrm{VI}}-$ $\mathrm{Ti}_{3}^{\mathrm{IV}} \mathrm{O}_{12}, M_{3}^{\mathrm{VIII}} M^{\mathrm{VI}} \mathrm{Ti}^{\mathrm{VI}} \mathrm{Si}_{3}^{\mathrm{IV}} \mathrm{O}_{12}$ and $\square^{\mathrm{VIII}} M^{\mathrm{VIII}} \mathrm{Ti}^{\mathrm{VIII}}$ $\mathrm{Al}_{2}^{\mathrm{VI}} \mathrm{Si}_{3}^{\mathrm{IV}} \mathrm{O}_{12}$ for garnet, and $M_{2}^{\mathrm{VI}} \mathrm{Ti}_{2}^{\mathrm{IV}} \mathrm{O}_{6}$ and $\square^{\mathrm{VI}} \mathrm{Ti}^{\mathrm{VI}} \mathrm{Si}_{2}^{\mathrm{IV}} \mathrm{O}_{6}$ for orthopyroxene. Here $M=\mathrm{Fe}, \mathrm{Mg}$;
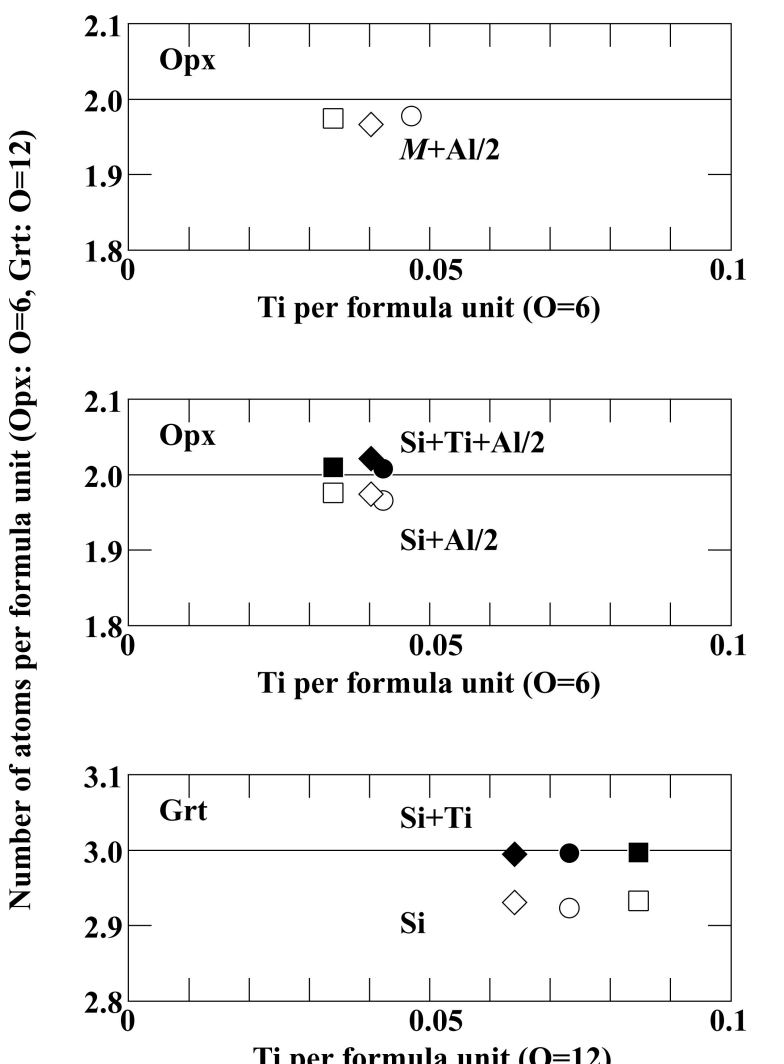

Figure 2. Plots of number of atoms in the tetrahedral and octahedral sites vs $\mathrm{Ti}$ in garnet and orthopyroxene in the MCTQ system. Circles: 15 kbar $/ 1200^{\circ} \mathrm{C}$; squares: $17.5 \mathrm{kbar} / 1200^{\circ} \mathrm{C}$; diamonds: $20 \mathrm{kbar} / 1300^{\circ} \mathrm{C}$.

and $\square$ is the vacancy in garnet and orthopyroxene. If the Ti occupies the octahedral site, the following numeric relations should be satisfied among numbers of elements $(N)$ :

$$
\begin{gathered}
N_{\mathrm{Si}}^{\mathrm{Grt}}+N_{\mathrm{Ti}}^{\mathrm{Grt}}>3, \\
N_{\mathrm{Al}}^{\mathrm{Opx}} / 2+N_{\mathrm{Si}}^{\mathrm{Opx}}+N_{\mathrm{Ti}}^{\mathrm{Opx}}>2, \\
N_{\mathrm{Mg}}^{\mathrm{Grt}}+N_{\mathrm{Fe}}^{\mathrm{Grt}}>3, \\
N_{\mathrm{Al}}^{\mathrm{Opx}} / 2+N_{\mathrm{Mg}}^{\mathrm{Opx}}+N_{\mathrm{Fe}}^{\mathrm{Opx}}<2 .
\end{gathered}
$$

In Figure 2 we present these relations obtained from our present experiments in the MCTQ system. Zhang et al. (2003) reported the Ti solubility increases with pressure as $M_{3}^{\mathrm{VIII}} M^{\mathrm{VI}} \mathrm{Ti}^{\mathrm{VI}} \mathrm{Si}_{3}^{\mathrm{IV}} \mathrm{O}_{12}$ accompanying increase of $\mathrm{Si}$ as $M_{3}^{\mathrm{VIII}} M^{\mathrm{VI}} \mathrm{Si}^{\mathrm{VI}} \mathrm{Si}_{3} \mathrm{IV}_{12}$ under the ultrahigh-pressure conditions $(>5 \mathrm{GPa})$. As is seen in Figure 2, the $\mathrm{Ti}$ in garnet would substitute for the tetrahedral Si without substitution of the octahedral $\mathrm{Al}$ for pressures of the ultrahigh-temperature granulites. In orthopyroxene the Ti could occupy the tetrahedral and octahedral sites.

Figure 3 shows the experimental data of the Tisolubility obtained from this study (MCTQ) and the previous study (RVH: Kawasaki and Motoyoshi, 2005), indicating that $\mathrm{Ti}$ in garnet and orthopyroxene increases with temperature. The Ti content would decrease with pressure in garnet and increase with pressure in orthopyroxene.

\section{Thermodynamics of Ti-solubility}

From the stoichiometric constraints, Ti partitioning is expressed by the following chemical reactions:

$$
\begin{aligned}
& \underset{\mathrm{Opx}}{M_{2} \mathrm{Si}_{2} \mathrm{O}_{6}}+\underset{\mathrm{Rt}}{2 \mathrm{TiO}_{2}} \underset{\mathrm{Opx}}{\rightleftharpoons} \underset{\mathrm{Ti}_{2} \mathrm{O}_{6}}{\rightleftharpoons}+\underset{\mathrm{SiO}}{2}, \underset{\text { Qtz }}{2} \\
& M_{3} \mathrm{Al}_{2} \mathrm{Si}_{3} \mathrm{O}_{12}+3 \mathrm{TiO}_{2} \rightleftharpoons M_{3} \mathrm{Al}_{2} \mathrm{Ti}_{3} \mathrm{O}_{12}+3 \mathrm{SiO}_{2} \text {, } \\
& \text { Grt } \quad \mathrm{Rt} \quad \mathrm{Grt} \quad \mathrm{Qtz} \\
& M_{2} \mathrm{Ti}_{2} \mathrm{O}_{6}+6 \mathrm{SiO}_{2} \rightleftharpoons 2 \square \mathrm{TiSi}_{2} \mathrm{O}_{6}+M_{2} \mathrm{Si}_{2} \mathrm{O}_{6} \text {. } \\
& \text { Opx Qtz Opx Opx }
\end{aligned}
$$

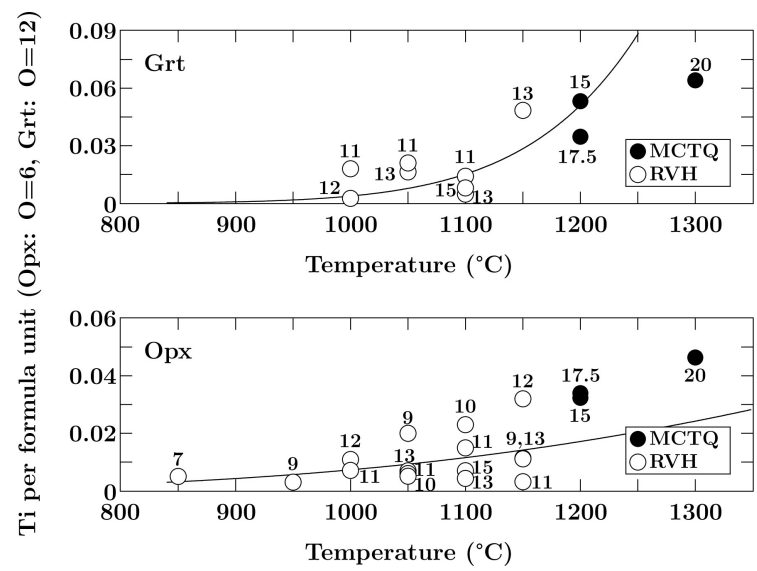

Figure 3. Solubility of Ti in garnet and orthopyroxene coexisting with rutile. Curves indicates the calculated solubility of $\mathrm{Ti}$ at mean pressures $15 \mathrm{kbar}$ for garnet and $12 \mathrm{kbar}$ for orthopyroxene by the following empirical equations:

$$
\begin{gathered}
\ln X_{\mathrm{Ti}}^{\mathrm{Opx}}=(-8810+1.369 T+67.1 P) / T \text { and } \\
\ln X_{\mathrm{Ti}}^{\mathrm{Grt}}=(-21310+13.664 T-231.3 P) / T,
\end{gathered}
$$

where $X_{\mathrm{Ti}}^{\mathrm{Grt}}$ and $X_{\mathrm{Ti}}^{\mathrm{Opx}}$ are the number of Ti atoms per formula unit narmalized by 12 and 6 oxygen atoms, respectively. Numerals indicate run pressures (kbar).

The thermodynamic treatment of the substitution of $\mathrm{Ti}$ on the octahedral sites is not established for the present. The Ti partitioning on the tetrahedral sites 
given by the reactions (5) and (6) are formulated by

$$
\begin{aligned}
-\Delta G_{5} & =R T \ln \frac{a_{M_{2} \mathrm{Ti}_{2} \mathrm{O}_{6}}^{\mathrm{Opx}}\left(a_{\mathrm{SiO}_{2}}^{\mathrm{Qtz}}\right)^{2}}{a_{M_{2} \mathrm{Si}_{2} \mathrm{O}_{6}}\left(a_{\mathrm{TiO}_{2}}^{\mathrm{Rt}}\right)^{2}} \\
& \simeq 2 R T \ln \frac{X_{\mathrm{Ti}}^{\mathrm{Opx}, \mathrm{IV}}}{X_{\mathrm{Si}}^{\mathrm{Opx}, \mathrm{IV}}} \\
-\Delta G_{6} & =R T \ln \frac{a_{M_{3} \mathrm{Al}_{2} \mathrm{Ti}_{3} \mathrm{O}_{12}}^{\mathrm{Ort}_{2}}\left(a_{\mathrm{SiO}_{2}}^{\mathrm{Qtz}}\right)^{3}}{a_{M_{3} \mathrm{Al}_{2} \mathrm{Si}_{3} \mathrm{O}_{12}}\left(a_{\mathrm{TiO}_{2}}^{\mathrm{Rt}}\right)^{3}} \\
& \simeq 3 R T \ln \frac{X_{\mathrm{Ti}}^{\mathrm{Gr}, \mathrm{IV}}}{X_{\mathrm{Si}}^{\mathrm{Grt}, \mathrm{IV}}},
\end{aligned}
$$

where $a$ and $X$ are the activity and mole fraction, respectively. Here we assume $a_{\mathrm{TiO}_{2}}^{\mathrm{Rt}} \simeq a_{\mathrm{SiO}_{2}}^{\mathrm{Qtz}} \simeq 1$ (Kawasaki and Osanai, 2007).
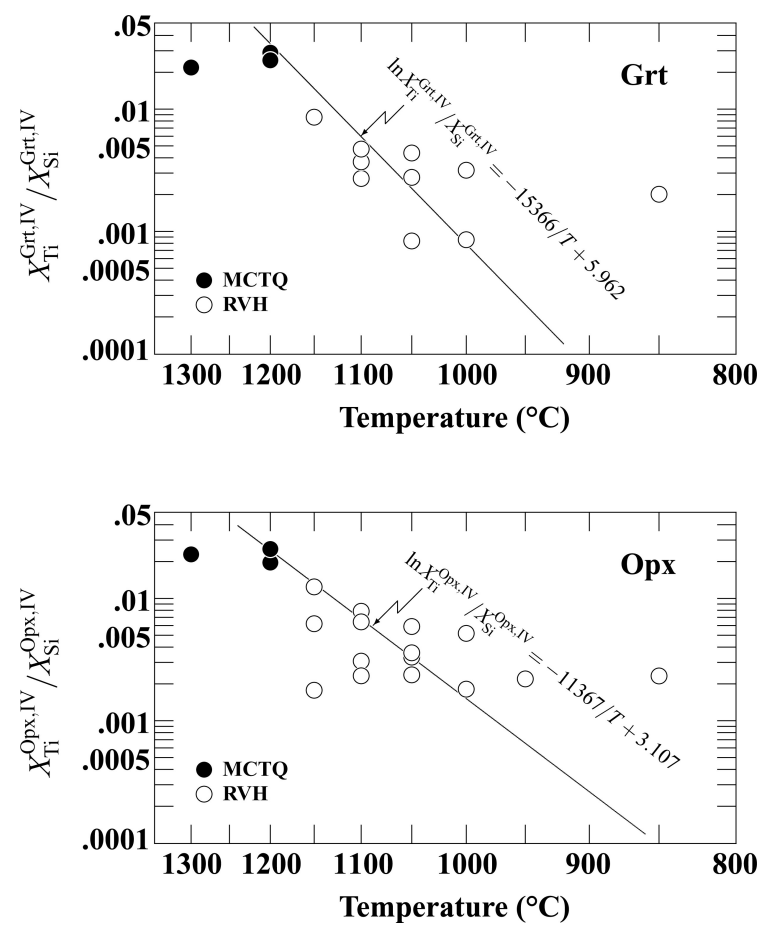

Figure 4. Temperature dependence of $\mathrm{Ti}$ in garnet and orthopyroxene. Curves indicates the calculated solubility of $\mathrm{Ti}$, ignoring the pressure dependence.

\section{Discussions and conclusions}

Temperature dependence of the Ti-solubility is calculated from the experimental data given in Figure 3 under Equations (8) and (9):

$$
\ln \left(X_{\mathrm{Ti}}^{\mathrm{Grt}, \mathrm{IV}} / X_{\mathrm{Si}}^{\mathrm{Grt}, \mathrm{IV}}\right)=-15366 / T+5.962
$$

and

$$
\ln \left(X_{\mathrm{Ti}}^{\mathrm{Opx}, \mathrm{IV}} / X_{\mathrm{Si}}^{\mathrm{Opx}, \mathrm{IV}}\right)=-11367 / T+3.107 .
$$

Results are illustrated in Figure 4. The Ti content in garnet is more dependent on temperature than that in orthopyroxene. As is clear, Ti content of garnet and orthopyroxene increases with temperature. A good fit implies the present thermodynamic model is available to describe the Ti solubility in garnet and orthopyroxene.

Using the Ti thermometers given by Equations (10) and (11), we obtain the peak and retrograde metamorphic temperatures of McIntyre granulite as 1079 and $798^{\circ} \mathrm{C}$, respectively, and the retrograde temperature of Rundvågshetta granulite as $884-921^{\circ} \mathrm{C}$. These data are consistent with our previous estimates. We conclude the Ti-solubility in garnet and orthopyroxene is a useful geothermometer to evaluate the metamorphic temperature of Antarctic granulites with high precision.

Acknowledgements. We have often discussed ultrahightemperature metamorphism and the anatexis of the lower crust with Yasutaka Yoshimura, Masaaki Owada, Yasuhito Osanai, Makoto Arima, Yoshikuni Hiroi and Kazuyuki Shiraishi. We obtained the idea of the present study through discussions with them. We express our hearty thanks to anoymous referees for their comments to improve this paper. Support from the Grant-in-Aid for Scientific Research from the Ministry of Education, Science and Culture of the Japanese Government no. 14654093 is gratefully acknowledged.

\section{References}

Dobrzhinetskaya, L.F., Green, H.W. II, and Wang, S. (1996), Alpe Arami: a peridotite massif from depths of more than 300 kilometers. Science, 271, 1841-1845.

Green, H.W. II, Dobrzhinetskaya, L.F, Riggs, E.M., and Zhen-Ming, J. (1997), Alpe Arami: a peridotite massif from the mantle transitiopon zone? Techtonophysics, 279, 1-21.

Kawasaki, T., and Motoyoshi, Y. (2000), High-pressure and hightemperature phase relations of an orthopyroxene granulite from McIntyre Island, Enderby Land, East Antarctica. Polar Geosci. $13,114-133$.

Kawasaki, T., Sato, K., Motoyoshi, Y. (2002), Experimental constraints on the thermal peak of a granulite from McIntyre Island, Enderby Land, East Antarctica. Gondwana Res., 4, 749-756.

Kawasaki, T., and Motoyoshi, Y. (2005), Experimental constraints on the decompressional $P-T$ path of Rundvågshetta granulites, Lützow-Holm Complex, East Antarctica, in Antarctica: Contributions to global earth sciences, edited by D.K. Fütterer, D. Damaske, G. Kleinschmidt, H. Miller, and F. Tessensohn, pp. 2336, Springer-Verlag, Berlin, Heiderberg, New York.

Kawasaki, T., and Osanai, Y. (2007), An empirical thermometer of $\mathrm{TiO}_{2}$ in quartz calibrated from ultrahigh-temperature granulites of East Antarctica. in Geodynamic Evolution of East Antarctica: a Key to the East-West Gondowana Connection, edited by M. Satish-Kumar, Y. Motoyoshi, Y. Osanai, Y. Hiroi, and K. Shiraishi, Geol. Soc. London, Spec. Pub. (in press).

Osanai, Y., Toyoshima, T., Owada, M., Tsunogae, T., Hokada, T., Crowe, W.A., and Kusachi, I. (2001), Ultrahigh temperature sapphirine-osumilite and sapphirine-quartz granulites from Bunt Island in the Napier Complex, East Antarctica - Reconnaissance estimation of $P-T$ evolution - Polar Geosci., 14, 1-24.

Osanai, Y., and Yoshimura, Y. (2002), High-tmperature limit of crustal metamorphism: a perspective of ultrahigh-temperature metamorphism. Chishitsu News, 573, 10-26 (in Japanese)

Song, S., Zhang, L., and Niu, Y. (2004), Ultra-deep origin of garnet peridotite from the North Qaidam ultrahigh-pressure belt, Northern Tibetan Plateau, NW China. Am. Mineral., 89, 1330-1336.

Wark, D.A., and Watson, E.B. (2006), TitaniQ: a titanium-in-quartz geothermometer. Contrib. Mineral. Petrol., 152, 743-754.

Zhang, R.Y., Zhai, S.M., Fei, Y.W., and Liou, J.G. (2003), Titanium solubility in coexisting garnet and clinopyroxene at very high pressure: the significance of exsolved rutile in garnet. Earth Planet. Sci. Letters, 216, 591-601. 